\title{
The sacred in beauty of the building space for meditation, prayer and liturgy
}

Architecture links the pragmatic and metaphysical dimension of the culture. This phenomenon of architecture is particularly visible in sacred buildings. Churches are also the signs of the sacred in the "semiotic landscape" of modern cities. The full meaning of sacred architecture is not only connected with the institutionalised forms of religious cult.

The value of location, plan composition, outlines' shapes, architectural detail make these buildings the reinterpretation of the sacred buildings' archetypes. In their forms we can interpret the meaning of universal symbols: a road, gate, nave, vault, tower, light and colours. We can find the sequences of these notions in modern buildings which semantic dimension lacks direct references to religion. The attributes typical of churches imitate architectural forms of museums, opera houses, theatres and shopping arcades ... The redefinition in the cultural space is deepened by the signs of "parasacralization" of its areas which have been connected so far with mass culture, entertainment or even commerce or consumption.

The ideas of the sacred and beauty - having been redefined for ages - still determine the nature of erected buildings which were religiously inspired. We can identify the elements of these ideas in diverse forms of space which is used for meditation, prayer and liturgy. The symbolic originators of their architecture, which contemporary-wise keep a particular power of message, are light and colours.

Key words: sacral architecture, the sacred, beauty, light, colour. 


\section{The complementarity of the idea of sacred and beauty origin}

Undertaking deliberations, which focus on the notions of the sacred and beauty, we intuitively follow the belief concerning close relations which are happening between them. In European culture's determinants they are in the character of relations happening between notions close in meaning, complementary and synonymous. In common understanding, the sacred and beauty belong to the sphere of metaphysical, universal, absolute and transcendent ideas. Hence their definition encounters complex problems. The record of scientific discourse concerning these ideas has had a long and content-rich history. It has been present in the major currents of philosophy for over two thousand years. For couple of centuries the integrity of these ideas has undergone atomization. It is theology which is a typical area for scientific description of the sacred, whereas beauty is in aesthetics domain. The modern interpretation concepts of these ideas favour their autonomy and at the same time they deprive them of universal and absolute character. The thesis which is in the title of the scientific conference "The Sacred in Beauty" inspires to redefine the archaic definitions of the sacred and beauty from a perspective which assumes their complementarity.

The complementarity of the sacred and beauty has been firmly rooted in western culture. We can find the links between them in axioms of the classical aesthetics, in aesthetic ideas of early Christianity, in the aesthetic concepts formulated in Carolingian circle, in aesthetic scholastic ideals as well as in numerous modern currents of philosophies. Formulated by philosophers of these epochs definitions of beauty corresponded to aspiring to discovering and understanding universal principles, rules and patterns present in the universe. The philosophical premise of the existence of universal order in the space was identical to accepting transcendent attributes of the Creator God - Absolute Being.

The divine origin of beauty is explained by Plato's Triad - Beauty, the Good and Truth:

- "The divine nature, which is fair, wise and good, and possessed of all other such excellences." (Phaedrus) ${ }^{1}$ 
- "All that is good is beautiful, and what is beautiful cannot lack proportion." (Timaeus) ${ }^{2}$

Aristotle is also emphasising in the definitions of beauty the links with absolute criteria of the good:

- "That, then, is Morally Beautiful or Noble, which being desirable for its own sake, is also laudable or which being good, is pleasant because good." (Rhetorica) ${ }^{3}$

The classical current defining the idea of Beauty is concluded by Vitruvius's theses:

- Beauty is the basic valuing category.

- Beauty is the equilibrium of functional and formal values.

- Beauty is on objective category conditioned by rights of nature but not the human's attitude - a human discovers these rights but does not invent them. ${ }^{4}$

Early Christian perspectives on this idea, formulated by St. Augustine, directly allude to ancient definitions of beauty. They became the keystone between classical aesthetics and the aesthetics of the European Middle Ages:

- "Unity is the form of all beauty." (Epist. $)^{5}$

- "The beauty of all things is derived, as it were, form antitheses, or contrasts." (De ordine) ${ }^{6}$

- "For the more measure, shape and order there is in all things, the better they are [...] these three are, as it were, general goods in things made by God, whether in spirit or in body." (De natura boni $)^{7}$

Boetius (480-525) directly refers to Aristotelean definitions of beauty:

- "Beauty appears to be a certain commensurateness of parts." (Topicorum Aristotelis interpretatio) ${ }^{8}$

Alcuin (735-804) - a scholar from the circles of Charlemagne - attributes to the values of sensory beauty the values which reflect the transcendent attributes of God - the Creator:

2 Tatarkiewicz, ed J.Harrel, p. 128.

3 Tatarkiewicz, ed J.Harrel, p. 163.

4 W. Tatarkiewicz, Historia estetyki 1. Estetyka starożytna, Wydawnictwo Arkady, Warszawa 1885, pp. 259-260.

$5 \quad$ W. Tatarkiewicz, ed. C Barrett, History of Aesthetics. Vol. II. Medieval Aesthetics, PWN - Polish Scientific Publishers, Mouton, The Hague, Paris, 1970, p. 60

6 Tatarkiewicz, ed. C Barrett, p. 61.

7 Tatarkiewicz, ed. C Barrett, pp. 60-61.

8 Tatarkiewicz, ed. C Barrett, p. 86. 
Theology of beauty

- "What easier than to love beautiful shapes, sweet tastes, pleasant sounds, fragrant, smells, things nice to the touch, and temporal honour and happiness? It is easy for the soul to love things which disappear like a fleeting shadow, and not to love God, who is eternal beauty, eternal sweetness, eternal charm, eternal fragrance, eternal delight and unceasing happiness." (Albini de rhetorica) ${ }^{9}$

The current of scholastic aesthetics is deepened by John Scotus Eriugena ( $9^{\text {th }}$ cent.) - a lay scholar at the Charles the Bald court:

- "Visible forms are not produced and shown to us for their own sake, but are notions of invisible beauty, by means of which Divine Providence recalls human minds into the pure and invisible beauty of truth itself." (In Hier. Coel. Dionysii I) ${ }^{10}$

- "He alone is truly worthy of love, because He alone is truly the highest goodness and beauty, and all which is known to be good or beautiful or worthy of love in things created this is God himself." (De divisione naturae, I, 74) ${ }^{11}$

Robert Grosseteste (1175-1253) - Franciscan, the bishop of Lincoln - undertakes the issues of aesthetics in theological treatises, as well as in mathematical theses and physical ones:

- "Beauty is that which contains everything in existence and combines it into one." 12

- "Thus God is the most perfect perfection, the fullest fullness, the shapeliest shapeliness and the most beautiful beauty." (De unica forma omnium $)^{13}$

In the main currents of scholastic aesthetics - of Bonaventure, referring to Plato and Augustine and Thomas of Aquinas, based on Aristotle - the idea of beauty appears in deliberations about God and world, nature and a human, cognition and action:

- "the world is beautiful because it is His creation and reflects his beauty." (Bonaventure) ${ }^{14}$

- "According to Pseudo-Dionysius, the notion of beauty comprises of both light and proper proportion [...] God is called the beauty

\footnotetext{
Tatarkiewicz, ed. C Barrett, p. 99.
}

10 Tatarkiewicz, ed. C Barrett, p. 104.

11 Tatarkiewicz, ed. C Barrett, p. 104.

12 Tatarkiewicz, ed. C Barrett, p. 229.

13 Tatarkiewicz, ed. C Barrett, p. 231.

14 Tatarkiewicz, ed. C Barrett, p. 232. 
because in all his things He is the cause of harmony and light." (Thomas of Aquinas) $^{15}$

In scholastic aesthetics, defining beauty on the basis of the attributes of transcendent God reaches the apogee. The absolutist perspectives on these relations in the next centuries gave way to relativist concepts. The characteristic circumstance of this watershed was the renaissance humanism. On the eve of modern times, there occurred a revival of philosophical discourse based on the reinterpretations of Plato's ideas and Aristotle's in the light of Christian theology. At the same time, in the aura of humanist boom the philosophers' attention until then drawn to universal ideas - also aesthetic - began to direct to subjecTheology of beauty tive values of the work of art and its creator - the artist gaining their autonomy. Universal notions characterizing so far the idea of beauty - harmony, order, excellence, the good, truth, brilliance - underwent relativization collating them with subjective notions - impression, pleasure, bliss, craftsmanship, fun, fiction.

Alberti - in his treatise on architecture dating back to $15^{\text {th }}$ century - still keeps the antique pattern of the dependence of beauty on its Creator:

- "Raising our eyes to heaven and looking at His miraculous works, we admire God more for the beauty which we see than for the usefulness which we sense."16

Nearly a hundred years after Alberti, a mathematician Luca Pacioli at the court of Milan, in the treatise published in 1509 on the proportions in architecture (De divina prportione) also refers to the classical aesthetics emphasizing the divine provenance of the beauty pattern:

- "[...] the art. of imitating nature to the greatest degree cannot be known to us if the Almighty One does not permit it, as Plato says with some secret intent in his Timaeus. These are things known only to God and to him who is His friend." 17

Faithful to the absolutist concept of the provenance of beauty is Michelangelo (1475-1564):

- "Through mortal beauty, thus I can behold and know my God; and I am free to love whatever so superbly mirrors Him."18

Leonardo Bruni, only at the beginning of $15^{\text {th }}$ century, formulated the view determining the primacy of the artist over the values of his works:

$15 \quad$ Tatarkiewicz, ed. C Barrett, p. 248.

16 Władysław Tatarkiewicz, ed. D. Petsch, History of Aesthetics. Vol. III. Modern Aesthetics, PWN - Polish Scientific Publishers, Mouton, The Hague, Paris, 1970.

17 Tatarkiewicz, ed. D. Petsch, p. 58.

18 Tatarkiewicz, ed. D. Petsch, p. 149. 
- "I admire the mind of the poet, but no means do I admire the work, knowing that it is a fiction." 19

Leonardo da Vinci's (1452-1519) views express the deification of artist's creative skills:

- "The divinity which is the science of painting transmutes the painter's mind into a resemblance of the divine mind. With free power it reasons concerning the generation of the diverse natures [...."20

In the face of modern relativization of the idea of beauty, there happened the "suspension" of the attempts of defining it:

- "But what beauty might be, that I know not." - Albrecht Dürer $1471-1528^{21}$

- "It is probable that we simply do not know what beauty is in nature, or in general, since we attribute so many different shapes to human beauty. If so kind of natural prescription for beauty existed, we would recognize it all alike, as we do the heat of flames. We devise the form of beauty in our phantasy." - Michel de Montaigne $(1533-1592)^{22}$

\section{The unified "beauty" of the parasacral spaces}

For couple of centuries in western culture, the idea of beauty has undergone relativization. One of its effects is blurring the essence of archetypal antinomies: beauty-ugliness, the sacred - the profane. The state of conceptual complication reflects the course of the discourse which has taken place around the concept of: art and anti-art, culture and anti-culture. Modern attempts of redefining the relations happening between the ideas of the sacred and beauty do not refer directly to the notions of: harmony, the good and truth. The substitute of the idea of beauty and the sacred in their modern definitions is the ambivalent concept "mystery":

- "The world is more beautiful just because it is a mystery" - Fyodor Dostoevsky (1821-1881) ${ }^{23}$

\footnotetext{
$19 \quad$ Tatarkiewicz, ed. D. Petsch, p. 77.

20 Tatarkiewicz, ed. D. Petsch, p. 136.

21 Tatarkiewicz, ed. D. Petsch, p. 258.

22 Tatarkiewicz, ed. D. Petsch, p. 270. 
- "[...] the search for beauty being the real secret of life." - Oscar Wilde (1854-1900) ${ }^{24}$

- "The most beautiful thing we can experience is the mysterious."Albert Einstein (1879-1955) ${ }^{25}$

The crisis in the sphere of concepts, meanings, values reflects the controversies about the criteria of shaping modern churches. Almost unlimited access of the sacred weakens its transcendent values. The direct result of such "popularization" is the free assimilation of symbols or the attributes of sacredness in all spheres of the environment shaped by the human. We are gradually accustoming with the characteristic forms of buildings, interior decoration or particular elements of their furnishings, which we interchangeably encounter in churches, concert halls, museums, shopping arcade, SPA centres, and also in our flats. Due to perception shaped in such a way, we are losing the sense of the identification of so-called sacral space with the sphere of religious experiences. The result of such redefinitions is a free creation of parasacral space. They are impoverished expressions of metaphysical orientation of human nature, which is characterized among others by the anthropological category of homo religious.

The attempts to redefine the ideas - the sacred, sacral space, sacral architecture - is compounded by the spreading process of desacralization of religious cult buildings. Dying out religious sense is a manifestation of secularization. Ensuing from that fact, numerous churches become fixed estate, whose value is reduced to an empty uninhabited building doomed to "utilization" or transformation into secular functions. It is economical aspects which greatly determine the direction of these redefinitions. Their primacy presents threats which effects result in deformations of architecture historical monuments and even it squanders irreversibly the unique values of cultural heritage. The processes of desacralization realized in line with the rules protecting against profanation or devastation lead more than one to spectacular "successes." The realization of original projects restore to societies historical churches in the form of e.g. concert halls, libraries or art galleries. At the same time - in equally valuable interiors of abandoned churches - what is arranged are luxurious hotels, private mansions, stylish restaurants or large format markets, skate parks or even nightclubs ..

24 http://www.online-literature.com/wilde/dorian_gray/4/ (14 February 2017)

25 http://www.goodreads.com/work/quotes/4681597-living-philosophies (14 February 2017) 
Theology of beauty

Paradoxically, the state of loss, accompanying shaping modern sacral buildings and protecting historical churches, is the source of the diversity of the churches architecture of our times. Contrary to widespread signs of secularization and desacralization, the places of religious cult are still appearing in the city space, which buildings assume the forms of community small chapels, parish church complexes, monasteries of monastic communities, bishop's cathedrals or monumental churches - monuments. Churches' outlines, integrated into panoramas of modern cities, are not the only forms of the emanation of the religious dimension of cultural space. Other forms constitute sacral buildings preserved from historical epochs; modern churches which refer to this type of monumental buildings as well as modern forms of religious cult places, which are integrated into buildings of secular functions. This type of buildings of various religious communities form a dispersed in a city structure network of chapels, oratory, prayer halls, Protestant churches. They function as religious centres of varied degree of accessibility. Architecture-wise they are often landscaping integrated into bigger, multifunction buildings or complexes of compound functional programme. The decision of locating the places of religious cult in such places is proved by the features in the form of religious symbols or elements of visual information. In these sacral spaces - deprived of monumental symbolism and iconographic narration, realized in the neighbourhood of urban living areas, the areas of study or work - the idea of "socializing the Church" is fulfilled. Today, the Houses of God are open "havens" for a human looking for a friendly place in a complex, alien world. As a result of these transformations, the metaphysical ideas of the sacred and beauty are leading inspirations in shaping the architecture of modern, multifunction "socialized churches." Then, which values, features, space parameters of this "utilitarian churches" trigger in their users the sense of presence in them the elements of the sacred and beauty?

\section{Light and colour - universal elements of beauty and the sacred in modern churches}

Light and colour are symbolic elements which have been shaping sacral spaces for ages - regardless of cultural and religious determinants. ${ }^{26}$ They also keep the distinct significance in modern sacral architecture. Light, creating the physical from of each building, at

$26 \quad$ J. Rabiej, Światto i kolor - uniwersalne walory architektury sakralnej, „Studia Teologiczno-Historyczne Śląska Opolskiego"(2015), no. 35, Opole 2015, p. 423-432. 

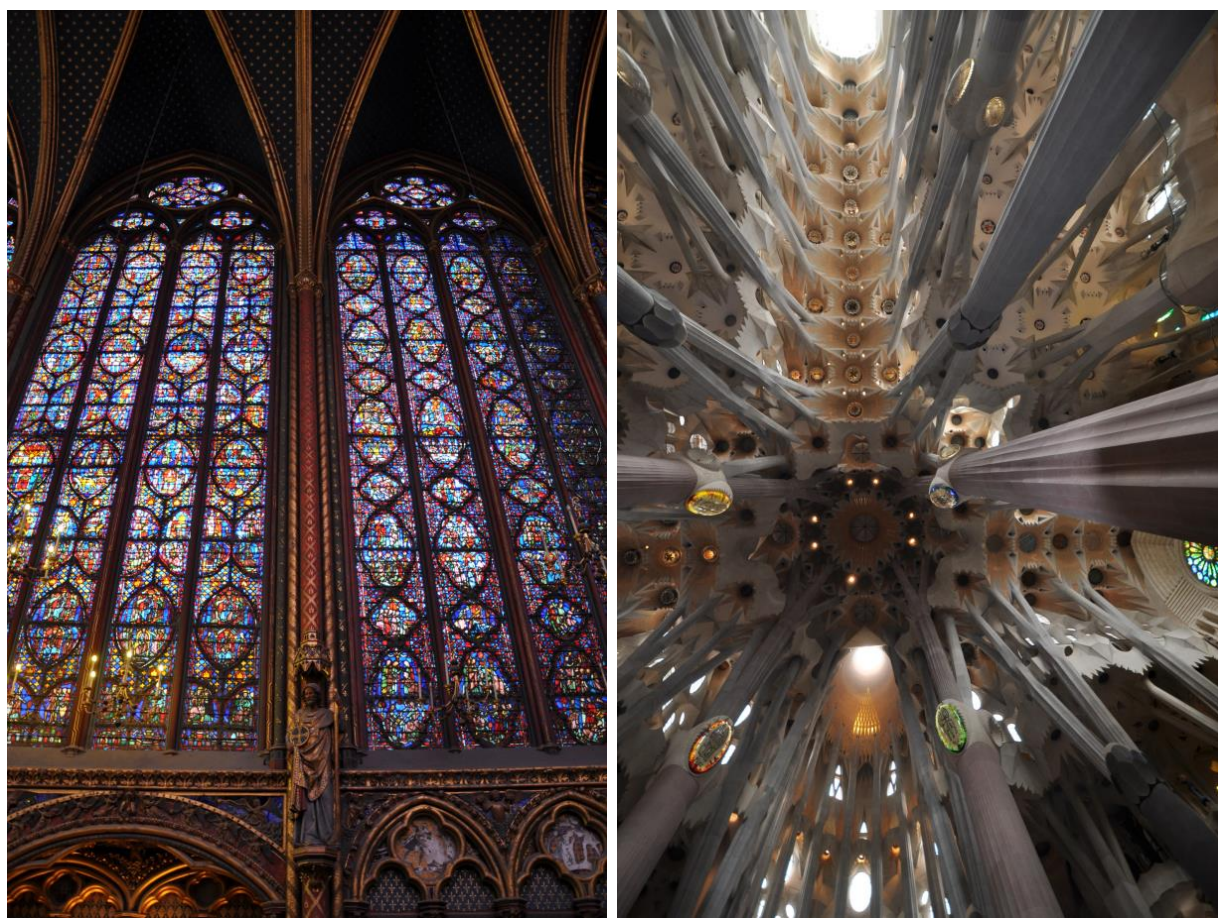

Theology

of beauty
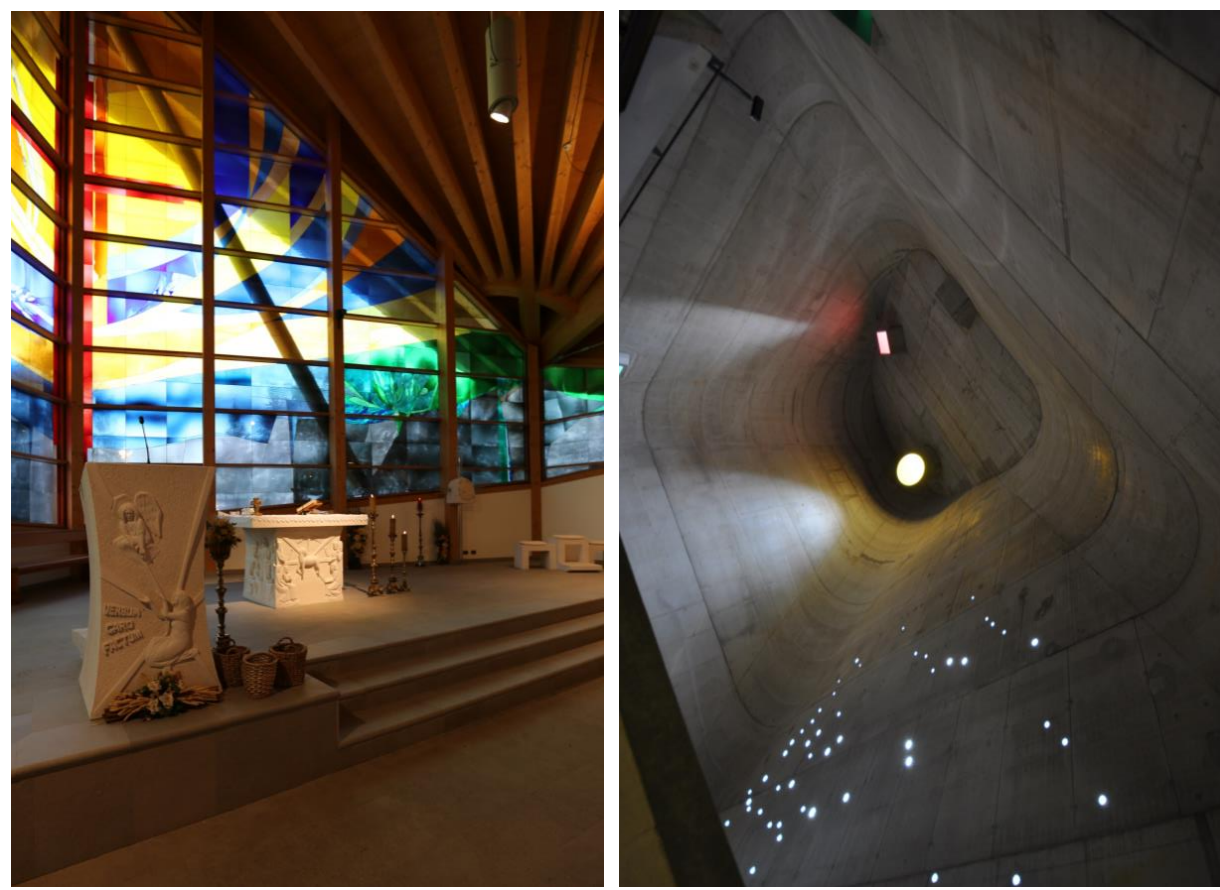

Fig. 1. Saint Chapelle chapel in Paris; Sagrada Familia church in Barcelona; church in Marilleva 1400; St. Paul's church in Firminy. 
Theology of beauty particular, highlights the shapes and atmosphere of a place, where a human meets with God. Light and colours are trans-religious "media", which create the aura of the sacredness in the places of cult, irrespective of their religious affiliation, the rules of canons or theological doctrines. Without them a human is seized by anxiety - the existential fear of void, darkness, nothingness ... We can find the expression of this archetypal awareness both in modern concepts of the sacral space, inspired by traditional patterns, and in modern churches, whose architecture seems to be consequently dissociated from historicizing style. In the architecture of churches, raised in the tone of polemics with modernism, the role of light and colour has undergone significant redefinitions. However, they remained as crucial semantic "creators" of modern churches. It turns out that numerous symbolic attributes of churches change their power of their significance, but the signs of light and colours still remain metaphysical "media." [Fig.1]

Shaping modern sacral architecture by referring to universal dimension of meanings, implanted in the symbols of light and colours, conceals in itself the hallmarks of paradox. What hinders the explicit message of ideas is potentially unlimited possibilities of creation which are nowadays available. In the postmodern reality - liberated from canons, pluralist and relativized - the impression of precise narration requires the absolute starkness of means, formal minimalism and technical perfectionism. Modern sacral spaces created in this current often evoke the impression of coldness - ideological void. Nevertheless, in many cases - keeping formal circumspection, which is within the convention of modern aesthetics - we find the values which decide about the sense of the sacred and beauty. They are triggered by light and colours. In the body of examples, they are the only, but ubiquitous symbols of absolute beauty. The potential evoking changing emotional state - from joyful excitement to ascetic calmness - underlies light and colours. Owing to light and colour, we reveal the spaces which predispose to concentration, mystic raptures, deep contemplation. They are these forms of expressions without which the phenomenon of unique churches-monuments fades. Their metaphysical nature requires light and colours, likewise only in their light the architectural forms of churches acquire sense. Owing to that fact, in three dimensional modern spaces of religious cult places we can intuitively discern the elements of the infinity. What arises from that concept is the picture of the universal church, which does not lose close relations with the earthly world while keeping the transcendent perspective. The metaphysical dimension of architectural space, "painted" with light 

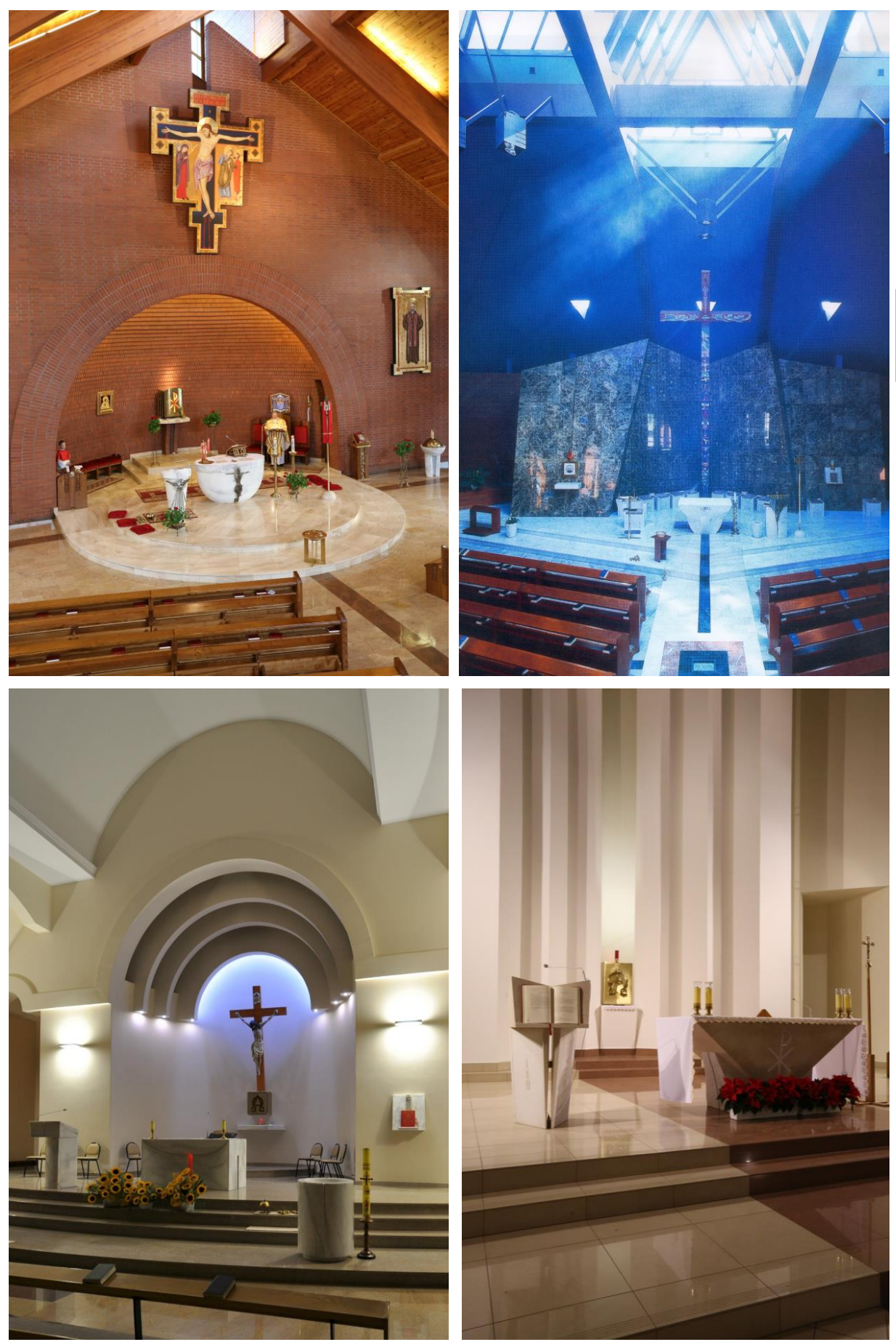

Theology of beauty

Fig. 2. St. Anthony's church in Mikołów; the Church of Mother of God, Mother of the Church in Katowice; Mother of Sorrows in Boruszowice; St. Hyacinth's church in Gliwice. 
(natural and artificial) and colours (of figurative and abstract compositions), is for a contemporary man - addicted to visual information - as meaningful as figurative narrations of colourful polychromes, icons, mosaics or stained glass [Fig. 2]. In abstract and symbolic values of light and colour the authors of modern churches find a transcultural and transreligious source of inspiration in the search for ecumenical concepts of sacral architecture.

During the act of raising modern churches - alike our predecessors in centuries past - we take part in unique, creative acts, which sense is to build the House of God, rationally integrated into the environment of the life of a society. Human nature - despite civilizational transformations - keeps integrity. It can be concluded by the triad of the anthropological attributes: homo socialis, homo symbolicus, homo religious. It is our existential awareness which draws from nature. It is shaped by a real experience of reality, set in time and space, here and now, and the intuitive sense of the transcendental reality - the Sacred, in which we can participate through the senses sensitive to the elements of absolute Beauty.

\section{SACRUM W PIĘKNIE PRZESTRZENI BUDOWANEJ DLA MEDYTACJI, MODLITWY I LITURGII}

Architektura spaja wymiar pragmatyczny z wymiarem metafizycznym kultury. Szczególnie czytelnymi wyrazami tego fenomenu architektury są budowle sakralne. Świątynie są również znakami sacrum w "krajobrazie semiotycznym” współczesnych miast. Pełny sens architektury sakralnej nie wiąże się wyłącznie $z$ instytucjonalnymi formami kultu religijnego.

Walory lokalizacji, kompozycje planów, kształty sylwet, detale architektoniczne czynią te budowle reinterpretacjami archetypów budowli sakralnych. W ich formach odczytujemy wymowę uniwersalnych symboli: drogi, bramy, nawy, sklepienia, wieży, światła i kolorów. Sekwencje tych pojęć rozpoznajemy także we współczesnych budowlach, których wymiar znaczeniowy pozbawiony jest bezpośrednich odniesień do religii. Przymioty właściwe świątyniom naśladują formy architektoniczne muzeów, oper, teatrów, galerii handlowych... Przewartościowania w przestrzeni kulturowej pogłębiają obecnie przejawy „parasakralizacji" tych jej obszarów, które dotąd związane były z kulturą masową, rozrywką, czy nawet handlem lub konsumpcją.

Idee sacrum i piękno - poddawane od wielu stuleci redefinicjom - wciąż wyznaczają istotę budowli wznoszonych z inspiracji religijnych. Pierwiastki tych idei identyfikujemy w różnorodnych formach przestrzeni, służących medytacji, 
modlitwie i liturgii. Symbolicznymi kreatorami ich architektury-zachowującymi współcześnie szczególną siłę wyrazu - są światło i kolor.

Słowa kluczowe: architektura sakralna, sacrum, piękno, światło, kolor.

\section{Bibliography:}

1. Rabiej J., Światto $i$ kolor - uniwersalne walory architektury sakralnej, „Studia Teologiczno-Historyczne Śląska Opolskiego” (2015), no. 35, Opole 2015, p. 423-432.

2. Tatarkiewicz W., ed. C Barrett, History of Aesthetics. Vol. II. Medieval Aesthetics, PWN - Polish Scientific Publishers, Mouton, The Hague, of beauty Paris, 1970.

3. Tatarkiewicz W., ed. J. Harrel, History of Aesthetics. Vol. I. Ancient Aesthetics, PWN - Polish Scientific Publishers, Mouton, The Hague, Paris, 1970.

4. Tatarkiewicz W., Historia estetyki 1. Estetyka starożytna, Wydawnictwo Arkady, Warszawa 1885.

5. Tatarkiewicz W., ed. D. Petsch, History of Aesthetics. Vol. III. Modern Aesthetics, PWN - Polish Scientific Publishers, Mouton, The Hague, Paris, 1970 . 